\title{
Civil Society in Lebanon: the Implementation Trap ${ }^{1}$
}

The term "civil society" generally refers to a variety of actors that are seperate from the state. For this report, we adopt a broad definition of civil society, that considers it as the "realm that exists between the state, the market, and the individual" (Kingston, 2013:6). It hence encompasses formal and informal structures, community associations (jam'iyat ahlia) (Ben Nefissa, 2002: 12), non-governmental organisations, syndicates, cooperatives, faith based organisations, and trade unions, amongst others.

In Lebanon, civil society has played an important role throughout history ${ }^{2}$ and saw a significant rise during the Chehabist developmentalist era (1958-1964), with the creation of voluntary-run associations that sought to steer away from sectarian identities, while adopting broad development objectives. The Civil War period (1975-1990) witnessed a realignment of the modes of actions towards services and relief efforts. After the Civil War, the civil society sector continued expanding (Kingston, 2008: 1), with civil society organisations bolstering their modes of action to encompass human rights and advocacy efforts. Archives show that an average of 250 organisations was created per year in the early nineties, post civil war era (Karam Karam in Ben Nefissa, 2002: 58). Figures from Daleel Madani ${ }^{3}$, suggest a peak in NGO creation after each of the - recurring - humanitarian crisis that the country witnesses. Hence, following the Israeli War on Lebanon in 2006 and the conflict in Syria in 2011, the associative sector saw a proliferation of new initiatives, campaigns, and organisations. An average of 50 registration requests to Daleel Madani's Civil Society Directory are received on a monthly basis.

Lebanon is said to have the "most diverse and active civil society in the region" (Hawthorne, 2005: 89). However, and in a context of relative liberalism, social and policy change seems limited. This can lead to raise questions as to the effectiveness and impact of the sector. To what extent are the legal, political, and funding environments governing the work of these organisations enabling or constraining? Are civil society actors "trapped" in implementing roles, keeping them from efficiently addressing contextual needs and issues, and reaching their targeted populations, thus undermining their potential impact?

\footnotetext{
${ }^{1}$ This report is written by Marie-Noëlle AbiYaghi, Léa Yammine, and Amreesha Jagarnathsingh, Lebanon Support. See: www.lebanon-support.org.

${ }^{2}$ Since the Nahda in the nineteenth century, according to Karam, 2006.

${ }^{3}$ Daleel Madani is a programme by Lebanon Support. It is Lebanon's civil society network, openly available on this link: www.daleel-madani.org.
} 


\section{Navigating the Lebanese legal and political system}

Compared to other countries in the region, Lebanon's legal landscape appears rather liberal, enabling the emergence of civil society organisations. The Lebanese Constitution includes few articles related to public freedoms, the most relevant to civil society organisations being Article 13: "[t]he freedom to express one's opinion orally or in writing, the freedom of the press, the freedom of assembly, and the freedom of association shall be guaranteed within the limits established by law." The main law governing the work of civil society organisations is the 1909 Ottoman Law of Associations. The law describes associations as " a group of several persons permanently unifying their knowledge or efforts for nonprofit objectives" (Article 1) and requires newly formed associations to notify the government after creation (Article 2). Moreover, it outlines prerequisites for establishment (e.g. Articles 4, 5), organisational structure and procedures (e.g. Articles 6, 7, 8), and demands associations' purposes and practices to comply with the Lebanese law (e.g. Articles 3, 10).

Despite this apparently liberal legal environment, the law attributes governmental authorities with large discretionary power, that is used to prevent "illegal" assemblies (International Center for Non-Profit Law, 2018). Non-abidance of the Lebanese laws can result in banning, excessive penalties, or even imprisonment (Lebanon Support, 2016). Moreover, some provisions of the Penal Code and the Audio-Visual Media Law "are used to prosecute individuals for criticizing the government" (International Center for Non-Profit Law, 2018). Nowadays, a pattern of prosecutions, whereby criminal charges are pressed for peaceful criticism towards government authorities can be distinguished (Human Rights Watch, 2018), and repression is used by state security actors to silence activists, further contributing to the shrinking space for freedom of expression. ${ }^{4}$

Indeed, in Lebanon, social media are often used by civil society actors such as NGOs, activists, journalists, but also by individuals as a means to spread news, denounce or raise awareness about issues, as well as express political opinions and organise collective actions. For example, the 2015 collective actions in the frame of the waste management crisis were launched on social media around collectives such as

\footnotetext{
${ }^{4}$ See the recently published Conflict Analysis Bulletin by Lebanon Support that sheds lights on the "Crackdown on social media by the Lebanese authorities":

https://civilsociety-centre.org/article/conflict-analysis-bulletin-issue-12-october-2018-focus-crackdownsocial-media-lebanese.
} 
\#YouStink. ${ }^{5}$

Many NGOs have recourse to online campaigns as a mode of action to mobilise supporters over their cause ${ }^{6}$. While the internet is considered as a powerful tool to spread information in a short time, many experts have warned about its limitations as an effective activism tool, as well as dangers such as cyber bullying, online harassments, theft of personal information, among others cybercrimes. In 2006, ISF created the Cyber Crime and Intellectual Property Rights Bureau in order to combat cyber crimes and enhance online security in Lebanon. However, this bureau has generated many controversies $^{7}$ since its establishment notably regarding the arbitrary enforcement of an outdated law ${ }^{8}$ from 1943 Penal Code, which criminalises defamation against public officials, the president, the Lebanese flag, or the national emblem. While freedom of speech and freedom of press are guaranteed by the Lebanese constitutions "within the limits established by the law", the penal code is often used as an attempt to silence critics by incriminating individuals over mere jokes, sarcastic comments, or any criticisms towards government officials and religious figures. ${ }^{9}$ This practice constitutes a threat to freedom of expression and reflects an increasingly shrinking space for free speech in Lebanon.

As such, a legal grey zone facilitates control over CSOs. Even CSOs complying with the Lebanese law face challenges, as they have to "navigate" the bureaucratic system, that is characterised by an unpredictable pattern and significant delays. For example, Helem, an LGBTIQ organisation, has yet to be granted the receipt of the Ministry of Interior, more than 10 years after its creation (AbiYaghi, 2013). This is reportedly due to the theme addressed by the NGO being deemed too "controversial," as homosexual relationships are still considered "contrary to nature" as per article 534 of the Penal Code. However, in spite of this, authorities have been collaborating with Helem on various occasions, notably on HIV prevention with the Ministry of Health.

Other emerging CSOs seeking to officially register have also reported over 6 months delay to receive their documents.

\footnotetext{
${ }^{5}$ See Lebanon Support's timeline on Waste Management Conflict: https://civilsociety-centre.org/timeliness/4923.

${ }^{6}$ See Lebanon Support's Map of Collective Actions in Lebanon to learn more about online campaigns here: https://civilsociety-centre.org/cap/collective action.

${ }^{7}$ Read: http://www.dailystar.com.lb/News/Lebanon-News/2016/Dec-07/384401-facts-on-anti-cybercrime-andintellectual-property-rights-bureau.ashx

${ }^{8}$ See: https://www.ifex.org/lebanon/2018/08/13/interrogations-online-activists/

${ }^{9}$ For example, it is prohibited to insult the president, national emblems (Article 384 Lebanese Penal Code), or the army (Article 157 Military Code of Justice).
} 
While official registration does entail formal benefits for CSOs (obtaining a legal status and opening a bank account, that attributes them with the right to receive, manage, and dispense financial resources), many collectives still prefer to operate without it. Registered CSOs have recently noted an increased scrutiny to the documentation shared with the Ministry of Interior, such as Minutes of Board elections meetings. ${ }^{10}$ Additionally, the Minister of Interior and Municipalities issued the decree no. 24/EM/2018 which would increase control and scrutiny over associations, according to new mechanisms to be determined by the Directorate General for Political Affairs and Refugees, in accordance with the provisions of the Law of Associations of 1909. This has raised many concerns among various civil society actors.

What is more, Lebanese banks are also subjecting CSOs to extreme examinations on the basis of further transparency and the fight against terrorism: Syrian nationals have not been able to collect due cheques in USD, transfers to local NGOs are being thoroughly investigated, while transfers to local NGOs (Lebanese, Syrian, and Palestinian) operating in Syria have been impossible, jeopardising their operations.

\section{CSOs and public action: a tale of instrumentalisation}

As the previous examples illustrate, understanding the civil society sector and its actors cannot be done in abstraction from its dynamics with the state, and the existing "political opportunity structures" (Tilly: 1978) ${ }^{11}$ in the context in which these actors operate. Indeed, "states and their regimes have important structuring effects on civil society, influencing its makeup, dynamics, and political influence" (Kingston, 2013:13). Lebanon's consociational liberal power-sharing regime offers a space for negotiation and political bargaining with civil society actors.

2005 marks a milestone in civil society trajectory in Lebanon, as well as the state's practices vis-à-vis civil society actors: before that year and the withdrawal of the Syrian Army from Lebanon, civil society associations were largely repressed and their actions hindered (Kingston 2013:76). The aftermath of 2005 witnessed a more liberal state approach towards the civil society sector as a whole, where the state reverted back to a

\footnotetext{
${ }^{10}$ As reported to the authors of this report.

${ }^{11}$ This concept refers to the extent in which power, repression (and facilitation), and opportunity (and threat) provide options for collective action. While it has been criticised for its structuralist tendencies, we find it heuristic to understand some of the challenges faced by civil society actors in contexts such as Lebanon.
} 
“soft power" approach to controlling CSO's work, reverting, among others, to clientele networks to expand their control over the civil society sector (AbiYaghi, 2012: 20).

The relative liberal atmosphere and the absence of a welfare state in Lebanon have historically provided opportunities for elites (political, social, and economic) to create and maintain informal dependency networks that contribute, in fine, to preserve the socio-political status-quo in the country. Advocacy efforts are hence transformed in maneuvering dependency dynamics in order to achieve sporadic advocacy goals. In this perspective, civil society actors appear to contribute to regime resilience (as argued by Kinston, 2013). For example, many campaigns tend to rely on the support of political or religious figures, without, however, pushing for law reforms (Daou, 2015).

\section{The trials and tribulations of concerted action}

Against the rather grim background of an increasingly shrinking operational space, horizontal solidarity networks among actors could appear to be a recourse for CSOs. As Kingston (2013:63) explains, there have been several attempts to create coordination mechanisms between NGOs since the Civil War, with for example the National Forum for Social Development (NFSD), the Lebanese NGO Forum (LNF), and le Collectif - the latter two also described as "silent and neutral" state partners (Karam, 2006:72). The post-war period saw a rise in small associations networks and "civil movements" focusing notably on advocacy, and characterised by a relative homogeneity of their base. While these contributed to expanding the public space during this period, their impact on the political space remained limited, as they failed to form autonomous links with the state and relied on confessional and clanic networks (Kingston, 2013).

More recently, since 2011, the Syrian refugee crisis has brought to the surface the limited leadership role of the Lebanese state, in regards to international donors' policies and agendas. The crisis has introduced a new humanitarian "market" to the country, with international actors that, in practice, have established a quasi monopoly on the coordination efforts and have ostracised local actors who undoubtedly have a thorough knowledge of the local social fabric and context (Mitri, 2015). They have contributed, on the other hand, through a policy of "ethnicization", to further deepen existing cleavages and tensions along ethnic or confessional lines between "beneficiary" categories, ie. Syrian refugees, and Lebanese host communities (Carpi, 2015). 
In addition, while networks and coordination platform do exist, they often appear to be project based and thus time- and resource-bound. These initiatives are frequently instigated by an international actor, and even when handed over to a local partner for the sake of localising and contextualising efforts, the network winds up stagnating (Lebanon Support, 2016: 17-18).

Another challenge voiced by local actors is the increasing disconnect between coalition thematics and the contextual needs on the ground. The former seems to abide by international programmatic agendas, rather than local ones. Hence, local actors find themselves operating a series of "adjustments" in order to fabricate relevance that would fit their contextual objectives to the donors' precepts. In practice, this leads to local actors "molding" their projects proposals to answer calls on international priorities, such as the Sustainable Development Goals: for example, an interviewed local organisation voiced how their international donors, 7 years into the Syrian refugee crisis, suggested they frame the same ongoing project, tackling peace building among refugees and host communities, as responding to an SDG thematic.

While networks abound, and dialogue platforms do exist, the limits within which they operate restricts exchange and dialogue between stakeholders in shaping national development policies. Indeed, when active, these networks are often limited to punctual and ad hoc activities, such as issuing press releases, and statements that may identify priorities, but rarely does that feed into national policies.

\section{Molding initiatives and tempering impact: actions in a logframe}

In a context of limited to no public government funds for civil society, this donor dependency also affects the direction of the programming of CSOs and their development policies. As local organisations have to resort to individual or institutional and international funding, they are tied by project constraints limiting their responses, interventions, and strategies. The dynamics governing these partnerships also tend to be skewed and to uphold the position of power of the donor, which impacts project development and overall cooperation.

Donors' formal requirements on local CSOs (on logistics, financial management, result based reporting, "monitoring and evaluation", etc.) have contributed to further push CSOs towards professionalisation. These formal requirements which are implemented in the perspective of increased transparency, are often viewed by local actors 


\section{Civil Society \\ Knowledge \\ $\because$ Centre}

interviewed for this report as mechanisms to further control them, and even impede on their institutional autonomy.

What is more, these dynamics could contribute to impose certain human rights based principles on local actors, who end up adopting this human rights language, but only in proposals and reports. This leads to local actors demonstrating their adherence to human rights principles semantically, but not necessarily integrating these in their approach. Hence, in practice, many CSOs working on social justice fail to implement internally and with their own staff basic labour and social security benefits.

While this NGOisation trend has been criticised by actors and scholars (Jad, 2007; Roy, 2016) as it notably renders organisations more logistically rigid and less reactive to contextual needs and opportunities, it has also created a need for ongoing and sustainable funding. Funding, thus, becomes the mere raison d'être of organisations, mainly concerned about their institutional perennity.

This constant "fund hunt" contributes to increase competition among local actors; this is also encouraged by donors practices who either tend to grant funds to medium and big sized organisations that are already in their networks, or even resort to creating on an ad hoc basis new "local" organisations, adding an additional level of restriction to access to funding.

It would not be an exaggeration to state that the proliferation of the number of the CSOs in Lebanon is an indicator of fragmentation rather than a characteristic of a "vibrant civil society" as some may argue. This fragmentation, in a context of limited cooperation and increased competition, is directly affecting the long term development and policy impact of CSOs. Indeed, associative actors that do appear to achieve concrete results are service oriented organisations. This, in addition to the aforementioned lack of a welfare state and the subsequent provision of social services and rights, contributes to the prevalence of a charity approach that further reinforces sectarian and communal reflexes rather than a civil and civic spirit (AbiYaghi, 2014), steering away from a human rights based approach fully integrated in their work, and rather adhering to standards and principles of human rights cosmetically, in their donors' proposals and reports. This local environment, thus, enables further confinement of CSOs to an implementation role, with limited development and policy impact.

This paper was originally published by the Arab NGO Network for Development, part of the Civic Space Watch, and is available on this link alongside reports from 5 other Arab countries.

\section{Bibliography}




\section{Civil Society \\ Knowledge \\ $\because$ Centre}

Marie-Noëlle AbiYaghi, Risha Jagarnathsingh (eds), “Unraveling 'Civil Society:' Policy, Dependency Networks, and Tamed Discontent. Reflections from Lebanon and Palestine," The Civil Society Review, Issue 3, Beirut, Lebanon Support, 2018.

Marie-Noëlle AbiYaghi, "Social Protection in Lebanon between charity and politics," Arab Watch 2014, Arab NGO Network for Development, December 2014.

Marie-Noëlle AbiYaghi, L'altermondialisme au Liban : un militantisme de passage. Logiques d'engagement et reconfiguration de l'espace militant (de gauche) au Liban, Université de Paris1-La Sorbonne, doctorat de science politique, 2013.

Marie-Noëlle AbiYaghi, "Civil Mobilization and Peace in Lebanon", in Elisabeth Picard, Alexander Ramsbotham, Reconciliation, reform and resilience. Positive Peace for Lebanon, Accord Publications, Issue 24, London, July 2012.

Sarah Ben Nefissa, Pouvoirs et associations dans le monde arabe, CNRS édition, 2002.

Estella Carpi, "The Everyday Experience of Humanitarianism in Akkar Villages," in Marie-Noëlle AbiYaghi, Bassem Chit, and Léa Yammine (eds), "Revisiting Inequalities in Lebanon, The case of the "Syrian refugee crisis" and gender dynamics," The Civil Society Review, Issue 1, Beirut, Lebanon Support, 2015, pp. 27-38.

Bernadette Daou, "Feminisms in Lebanon: after proving loyalty to the "Nation", will the "Body" rise within the "Arab Spring”?", in Marie-Noëlle AbiYaghi, Bassem Chit, and Léa Yammine (eds), "Revisiting Inequalities in Lebanon, The case of the "Syrian refugee crisis" and gender dynamics," The Civil Society Review, Issue 1, Beirut, Lebanon Support, 2015, pp. 55-68.

Amy Hawthorne, "Is Civil Society the Answer?", in Thomas Carothers and Marina Ottaway (ed.), Uncharted Journey: Promoting Democracy in the Middle East, Washington DC, Carnegie Endowment for International Peace, 2005, p. 90.

Islah Jad, "The NGO-Ization of Arab Women's Movements," in Feminisms in Development: Contradictions, Contestations and Challenges, Zed Books, 2007, pp. 177-90. 


\section{Civil Society \\ Knowledge \\ $\because$ Centre}

Karam Karam, Le Mouvement Civil Au Liban, Revendications, Protestations et Mobilisations Associatives Dans L'Après-Guerre, France, Editions Karthala - Iremam, 2006.

Paul Kingston, Reproducing Sectarianism. Advocacy networks and the politics of civil society in Lebanon, Albany, State University of New York, 2013.

Lebanon Support, "The Basic Guidebook for Emerging Collectives, Cooperatives and NGOs in Lebanon," Civil Society Knowledge Centre, Beirut, 2016.

Lebanon Support, "Overview of Gender Actors \& Interventions in Lebanon," Civil Society Knowledge Centre, Beirut, 2016, pp.17-18.

Dalya Mitri, "From Public Space to Office Space: the professionalization/NGOization of the feminist movement associations in Lebanon and its impact on mobilization and achieving social change," in Marie-Noëlle AbiYaghi, Bassem Chit, and Léa Yammine (eds), "Revisiting Inequalities in Lebanon, The case of the "Syrian refugee crisis" and gender dynamics," The Civil Society Review, Issue 1, Beirut, Lebanon Support, 2015, pp. 87-96.

Arundhati Roy, The End of Imagination, Chicago, Haymarket Books, 2016.

Charles Tilly, From Mobilization to Revolution, Reading, Mass. Addison-Wesley, 1978. 